\title{
Decolorization of Synthetic Dyes by Crude Laccase from Lentinus Polychrous Lev.
}

\author{
Karnika Ratanapongleka and Jirapa Phetsom
}

\begin{abstract}
In the present study, the addition of copper (2mM) to the fungus $L$. polychrous cultivated in solid media influenced the laccase activity. Laccase production was increased in the presence of copper and reached a maximum activity of 145 $\mathrm{U} / \mathrm{ml}$ on $12^{\text {th }}$ day. Crude laccase was capable to decolorize different dye structures. The enzyme showed great decolorization efficiency toward Acid Blue $80 \quad(85 \%$ decolorization in 120 min). Reaction kinetics of the enzyme on Acid Blue 80 followed Michaelis-Menten behavior and the initial rate of decolorization depended on the dye concentration. The kinetic parameters of the enzyme were determined and calculated from Lineweaver-Burk plots. The results indicated that the $K_{m}$ value was $0.36 \mathrm{mM}$ and $V_{\max }$ value was 0.0017 $\mathrm{mM} / \mathrm{min}$. The $\mathrm{pH}$ value for maximum decolorization of Acid Blue 80 was 5.0.
\end{abstract}

Index Terms-Decolorization, laccase, Lentinus polychrous.

\section{INTRODUCTION}

Synthetic dyes have been broadly used in many industries, especially in textiles. Large amounts of chemically different dyes generated by the textile industry are discharged to the environment and they become a major concern in wastewater treatment, since most synthetic dyes have complex aromatic structure which are largely toxic, mutagenic, carcinogenic and biodegradable difficulty [1]. Furthermore, they damage the esthetic nature of water and reduce light penetration through the water's surface, and also the photosynthetic activity of aquatic lives. Among these dyes, azo, anthraquinone and indigo are the major chromophores which are found in commercial dyes [2]. Decolorization by conventional wastewater treatment is inefficient. The physical and chemical treatments such as precipitation, photo degradation, adsorption and chemical degradation are costly, time-consuming and often methodologically demanding [3].

At present, a number of studies have focused on white rot fungi which have the capability to degrade various xenobiotic compounds including dyes since they produce some of the extracellular ligninolytic enzymes such as lignin peroxidase, manganese peroxidase and laccase [4]. The enzymatic treatment is simple and more flexible than the use of fungi cultures. Laccases have been received a great attention due to theirs efficiency and low cost degradation of

Manuscript received September 8, 2013; revised November 10, 2013 This work was financial supported by Ubon Ratchathani University, Thailand.

K. Ratanapongleka is with the Chemical Engineering Department, Faculty of Engineering, Ubon Ratchathani University, Ubonratchathani 34190, Thailand (e-mail: k_ratanapongleka@ubu.ac.th).

J. Phetsom is with the Biology Department, Faculty of Science, Mahasarakham University, Kantharawichai District, Maha Sarakham 44150, Thailand (e-mail: phetsom2000@yahoo.com). the organic pollutants including synthetic dyes [1].

Laccase is a multi copper oxidase and be capable of catalyzing the oxidation of a wide range of phenolic compounds and aromatic amines through the reduction of molecular di-oxygen to water [5]. Due to their ability to oxidize broad substrates, laccases have been extensively applied in several fields, such as decolorization of dyes, degradation of xenobiotics, pulp and paper industry, denim bleaching, food industry and organic synthesis. The capability of many microorganisms (fungi, insects and bacteria) on laccase production has been reported. The recent studies indicate that most fungi, especially white rot fungi, produce high yields of extracellular laccase [6]. Laccase production can be considerably stimulated by the presence of a wide variety of inducing substances, mainly aromatic or phenolic compounds related to lignin or lignin derivatives. In addition the effect of copper on stimulating laccase production has been reported especially in several Trametes spp [7].

In this study, the enzyme laccase was extracted from white-rot fungus Lentinus polychrous. The production of laccase stimulated by copper was explored. In particular, this work aimed to study the capability of crude laccase on decolorizing different dye groups. Seven synthetic dyes (i.e. Reactive Black 5, Reactive Orange 16, Reactive Green 19, Methyl Orange, Indigo Camine, Acid Blue 80 and Water Blue) were tested. Although the capabilities of laccase from $L$. polychrous on decolorization have been reported for a number of dyes such as RBBR, Bromophenol Blue, Methyl Red, and Congo Red [8,9], no kinetics analysis has been presented. In this paper, kinetics of crude laccase on Acid Blue 80 and optimum $\mathrm{pH}$ for decolorization were then investigated.

\section{EXPERIMENTAL}

\section{A. Fungi and Culture Conditions}

The fungus L. polychrous was obtained from Rujira Farm, Kalasin, Thailand. The strain was maintained on potato dextrose agar (PDA) plates at $4{ }^{\circ} \mathrm{C}$ and sub-cultured at least every 3 months.

Corn husk, rice bran and rice husk were used as mixed solid media for laccase production. The ratio of corn husk, rice bran and rice husk was 1:1:1 and the moisture content were controlled at $65 \%(\mathrm{w} / \mathrm{w}) .2 \mathrm{mM}$ of $\mathrm{CuSO}_{4}$ were added to the media in order to stimulate the production of laccase. Culture media were then sterilized at $121^{\circ} \mathrm{C}$ for $15 \mathrm{~min}$. Five agar plugs of an active fungus on PDA were aseptically cut and inoculated into the production media. The fungi were cultivated at $28{ }^{\circ} \mathrm{C}$ in the dark for 20 days. 


\section{B. Crude Laccase Extraction and Laccase Activity}

Crude laccase enzyme was prepared using water extraction. A 3:1 ratio of water and media was used for extraction. The mixed solution was filtered through miracloth and centrifuged at $4,000 \mathrm{~g}$ for 10 minutes. The supernatant was defined as crude laccase and kept at $4{ }^{0} \mathrm{C}$ for further study.

Laccase activity was determined following the change in optical density at $420 \mathrm{~nm}$ using 2, 2'-azino-bis (3-ethylbenzthiazoline-6-sulfonate (ABTS) as a substrate $(\varepsilon$ $=36,000 \mathrm{M} \mathrm{cm}$ ). Briefly, the assay mixture consisted of 0.1 $\mathrm{M}$ acetate buffer $\mathrm{pH} 4.5,10 \mathrm{mM}$ ABTS and enzyme. The mixture was incubated at $32{ }^{\circ} \mathrm{C}$ for $10 \mathrm{~min}$ and stopped the reaction with $50 \%(\mathrm{w} / \mathrm{v})$ TCA. One unit of enzyme was defined as the amount of enzyme required to oxidize $1 \mu \mathrm{mol}$ ABTS per minute. All assays were carried out in triplicate.

\section{Effect of Salts and EDTA on Laccase Activity}

The effect of salts on laccase activity was tested with $\mathrm{NaCl}$, $\mathrm{Na}_{2} \mathrm{SO}_{4}$ and $\mathrm{Na}_{2} \mathrm{CO}_{3}$. All salts including EDTA were used at a final concentration of 5,10 and $50 \mathrm{mM}$. The reaction mixture consisted of $100 \mathrm{mM}$ acetate buffer $\mathrm{pH} 4.5,10 \mathrm{mM}$ ABTS and $0.125 \mathrm{U} / \mathrm{ml}$ of crude laccase.

\section{Decolorization Assay}

Three structural groups of dyes (azo, indigoid and anthraquinone) were selected in this study. All dyes (Reactive Black 5, Reactive Orange 16, Reactive Green 19, Methyl Orange, Indigo Camine, Acid Blue 80 and Water Blue) were purchased from Sigma-Aldrich. The stock solution of dye was prepared by dissolving in distilled water. The desired dye concentration was prepared from the stock solution by dilution.

The reactions were carried out directly in the spectrophotometer cuvette. The reaction mixture consisted of crude laccase and an aqueous solution of dye in phosphate buffer $\mathrm{pH} 7.0 \mathrm{in}$ a total final volume of $3 \mathrm{ml}$. The cuvette was then inverted using paraffin as a cover, in order to achieve the homogeneity of the mixture prior to the measurement. Decolorized activity was determined by monitoring the decrease in absorbance on a spectrophotometer at a maximal absorbance of each dye (360-630 nm) and expressed in terms of percentage. All experiments were done in triplicate. Controls contained the individual dyes solution with inactive enzyme.

\section{E. Effect of Initial Dye and Laccase Concentration on Acid Blue 80 Decolorization}

The effect of Acid Blue 80 concentration on the enzymatic decolorization was monitored with different concentrations ranging from 20 to $140 \mathrm{mg} / \mathrm{l}$ in acetate buffer $\mathrm{pH}$ 5.0. The crude enzyme was used at $0.125 \mathrm{U} / \mathrm{ml}$. To test the effect of enzyme quantity, reaction was started with different quantities of enzyme $(0.003,0.006,0.012,0.025,0.062$ and $0.125 \mathrm{U} / \mathrm{ml}$ ). The dye concentration was fixed at $20 \mathrm{mg} / \mathrm{l}$ in buffer $\mathrm{pH}$ 5.0. The reaction was carried out at room temperature.

\section{F. Effect of $p H$ and Temperature on Acid Blue 80 Decolorization}

The effect of $\mathrm{pH}$ on decolorization was tested at different $\mathrm{pHs}$ ranging from 2 to 9 . The $\mathrm{pH}$ of reaction mixture was adjusted by citrate-phosphate and Tris- $\mathrm{HCl}$ buffer. To determine the effect of temperature on Acid Blue 80 decolorization, the reaction mixture $(\mathrm{pH} 5.0)$ was incubated under a temperature range between 30 and $60{ }^{0} \mathrm{C}$. The concentration of crude enzyme was controlled at $0.125 \mathrm{U} / \mathrm{ml}$.

\section{RESULTS AND DISCUSSION}

\section{A. Laccase Production}

The production of extracellular laccase from L. polychrous in the presence of $\mathrm{Cu}^{2+}$ was studied (Fig. 1). L. polychrous cultured in natural medium with and without copper was able to produce laccase. During the first week of cultivation, small amounts of laccase were produced (data not shown). The enzyme activity increased obviously after 7 days of cultivation. The presence of $\mathrm{Cu}^{2+}$ in the medium slightly increased the level of laccase activity. The highest laccase activity (145 U/L) was obtained in medium with copper. Laccase production in the absence of $\mathrm{Cu}^{2+}$ gave maximum on $14^{\text {th }}$ day $(103 \mathrm{U} / \mathrm{L})$ while in the presence of $\mathrm{Cu}^{2+}$ was on $12^{\text {th }}$ day. It is found that in the presence of inducers many white rot fungi can produce high amounts of laccase into the medium. This study shows that copper induces laccase production of $L$. polychrous. Similar inductive effect of $\mathrm{Cu}^{2+}$ on laccase production has been reported earlier in $P$. ostreatus [10] and T. trogii [2], [11]. Zheng et al. [12] indicated that copper could act as an inducer of enzyme activity by affecting the genetic transcription levels in which along with more copper involved in McoA-laccase synthesis. However, copper requirements are usually satisfied at very low concentrations. The presence of $4 \mathrm{mM} \mathrm{CuSO}_{4}$ inhibited the growth of $P$. hauseri and the cells were almost killed at $4.5 \mathrm{mM} \mathrm{CuSO}_{4}[12]$.

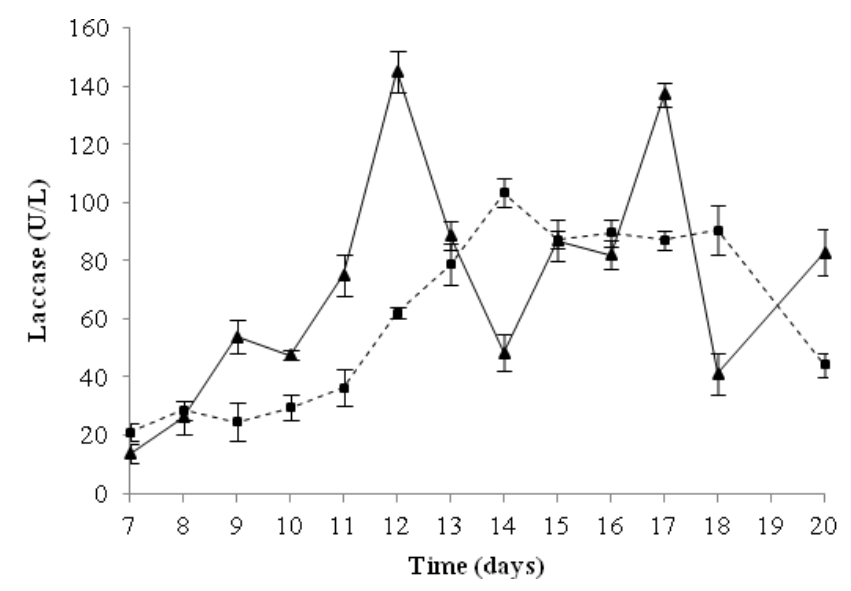

Fig. 1. Production of laccase as a function of time in the ( $\boldsymbol{\square})$ absence and $(\boldsymbol{\Delta})$ presence of $\mathrm{Cu}^{2+}$.

\section{B. Effect of Salts and EDTA on Laccase Activity}

In addition to dyes, high concentrations of salts have been found in textile industrial effluents and their presence can affect enzyme activity. In this study, the effect of salts and EDTA on laccase activity was tested at various concentrations, namely 5, 10 and $50 \mathrm{mM}$. It can be seen in Table 1 that laccase activity was significantly inhibited when high amounts of sodium chloride were added. While in the presences of $50 \mathrm{mM}$ of both $\mathrm{Na}_{2} \mathrm{SO}_{4}$ and $\mathrm{Na}_{2} \mathrm{CO}_{3}$ enhanced the activity. A similar behavior of $\mathrm{NaCl}$ on laccase activity 
was mentioned in laccase from Ganoderma lucidum [13].

EDTA, an organic compound used in many manufacturing processes, decreased laccase activity at high concentration. An inhibition by EDTA was also reported in the laccase from Trametes versicolor [14] and Pseudomonas desmolyticum [15], Bacillus sp. ADR [16].

TABLE I: EFFECT OF SALTS AND EDTA ON LACCASE ACTIVITY

\begin{tabular}{llll}
\hline Chemicals & \multicolumn{3}{c}{ Relative activity (\%) } \\
\cline { 2 - 4 } & $5 \mathrm{mM}$ & $10 \mathrm{mM}$ & $50 \mathrm{mM}$ \\
\hline $\mathrm{NaCl}$ & 95.1 & 80.7 & 40.3 \\
$\mathrm{Na}_{2} \mathrm{SO}_{4}$ & 93.3 & 98.0 & 125.9 \\
$\mathrm{Na}_{2} \mathrm{CO}_{3}$ & 71.3 & 57.8 & 125.1 \\
$\mathrm{EDTA}$ & 78.2 & 75.7 & 65.4 \\
\hline
\end{tabular}

\section{Dye Decolorization by Crude Laccase}

In general, the efficiency of decolorization depends on the structure of dye and the redox-potential of the enzyme [17]. The ability of crude laccase from $L$. polychrous to decolorize various structural dyes was examined. Several azo (Reactive Black 5, Reactive Orange 16, Reactive Green 19, Methyl Orange) indigoid (Indigo Camine) and anthraquinonic dyes (Acid Blue 80, Water Blue) were used in this experiments. These dyes were tested at $\mathrm{pH} 5.0$ where the enzyme performed a great activity to ABTS (acidic condition). The decolorization obtained at $120 \mathrm{~min}$ showed different percentages in each case. The anthraquinonic Acid Blue 80 and Water Blue were largely decolorized (up to $85 \%$ and $30 \%$ respectively) comparing to other dye groups. Indigo Carmine was decolorized only $20 \%$ whereas less than $10 \%$ decolorization of all the azo dyes was achieved. These results indicate that crude laccase decolorizes anthraquinonic dye more efficiently than other dye groups. Similar trends of dye decolorization on three structural groups were observed for crude laccase from Trametes trogii [2] and immobilized laccase from Trametes versicolor [18]. Ciullini et al. [2] explained that laccases show substrate specificities and the chemical structures of the dyes due to the differences in electron distribution, charge density and steric hindrances. Azo dyes are very recalcitrant as they have been developed to withstand bleaching by UV-light and detergents. Therefore, decolorization rate of azo dyes can be improved by the addition of some soluble redox mediators.

\section{Effect of Initial Dye and Laccase Concentration on Acid Blue 80 Decolorization}

The effect of Acid Blue concentration on decolorization was investigated by increasing the dye concentration from 20 to $140 \mathrm{mg} / \mathrm{l}$. The enzyme decolorized dye up to $85 \%$ in 180 min when the concentration used was below $50 \mathrm{mg} / \mathrm{l}$. The percent of decolorization decreased at higher dye concentrations (data not shown). The correlation between decolorization rate and dye concentration followed the Michaelis-Menten behavior. Good linearity was observed by Lineweaver-Burke plot, with regression values of 0.97 (Fig. 2 ). The apparent $K_{m}$ and $V_{\max }$ values of crude laccase were $0.36 \mathrm{mM}$ and $0.0017 \mathrm{mM} / \mathrm{min}$ respectively. The $\mathrm{V}_{\max }$ shows the maximum rate of reaction, which occurs when laccase is completely saturated with dye. The $\mathrm{K}_{\mathrm{m}}$ value indicates a measure of the dissociation of laccase-dye complex. Michniewicz et al. [19] reported that the $\mathrm{K}_{\mathrm{m}}$ values for dye oxidation varied depending on dyes and these $\mathrm{K}_{\mathrm{m}}$ values of purified laccase were lower than of the crude laccase, which indicated a higher affinity of the purified enzyme to the dye.

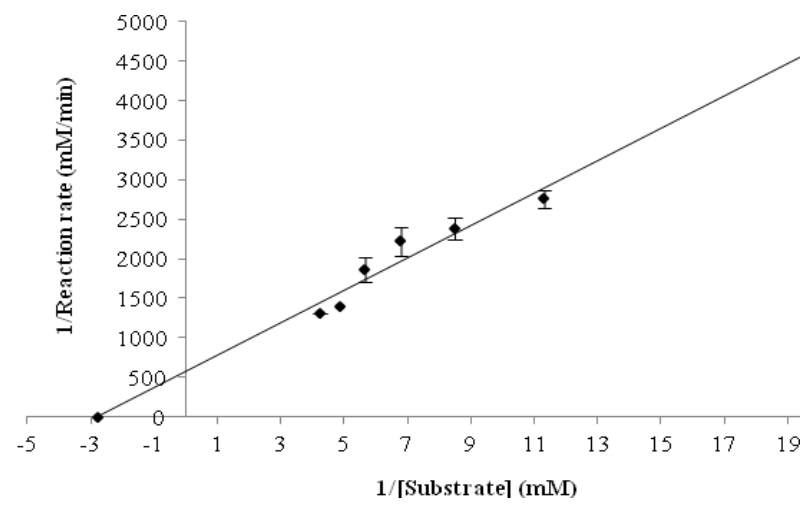

Fig. 2. Lineweaver-Burk plot for crude laccase activity with varying Acid Blue 80 concentrations.

The effect of enzyme concentration on decolorization was determined by increasing laccase activity from $0.003 \mathrm{U} / \mathrm{ml}$ to $0.125 \mathrm{U} / \mathrm{ml}$ with dye concentration of $20 \mathrm{mg} / \mathrm{l}$. The ability of dye decolorization increased with enzyme concentration. Plotting of initial rate versus enzyme concentration indicated that rate of decolorization within $10 \mathrm{~min}$ reaction seemed to be linearly proportional to the enzyme concentration when using enzyme up to $0.025 \mathrm{U} / \mathrm{ml}$ (Fig. 3). The reaction rate slowly increased at enzyme concentration of $0.062-0.125$ $\mathrm{U} / \mathrm{ml}$. The progress curve shows a hyperbolic form. The reaction rate tends to almost reach a maximum rate when higher enzyme concentration is used.

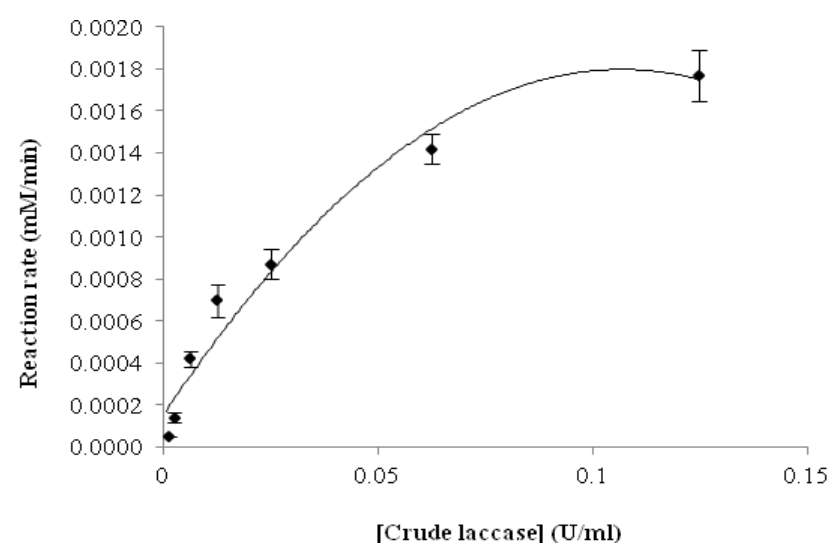

Fig. 3. Effect of crude laccase concentration on initial reaction rate of decolorization.

\section{E. Effect of pH and Temperature on Acid Blue 80 Decolorization}

The effect of $\mathrm{pH}$ on decolorization of Acid Blue 80 was monitored at $\mathrm{pH}$ ranging from 2 to 9 at $30{ }^{\circ} \mathrm{C}$ (Fig. 4). The $\mathrm{pH}$ has a major effect on the efficiency of dye decolorization. The profile showed maximum decolorization efficiency around $\mathrm{pH}$ 5.0. Then laccase decolorization activity started to decrease sharply and less than 5\% decolorization was observed at $\mathrm{pH}$ above 8 . In general, laccase enzyme tends to react differently to $\mathrm{pH}$ with different types of dyes. Other 
studies reported [8], [9], [18] optimum $\mathrm{pH}$ of laccase from $L$. polychrous on decolorization of RBBR, Bromophenol Blue, Methyl Red, and Congo Red were at $\mathrm{pH}$ 3.0, 4.0, 4.0-5.0 and 6.0-7.0, respectively. These results show that laccase from $L$. polychrous prefers acidic condition for dyes decolorization and laccases from other whit-rot fungi for example Ganoderma lucidum [13] and Trametes trogii [1] exhibite great activity at acidic condition as well. Grassi et al.[1] mentioned that the limitation for the use of white-rot fungal enzymes for dye decolorization was their acidic $\mathrm{pH}$ range of activity.

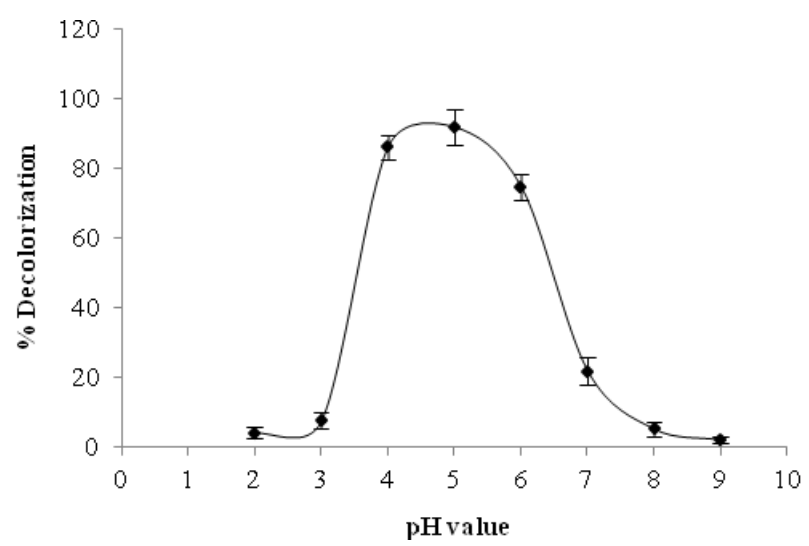

Fig. 4. Effect of $\mathrm{pH}$ on decolorization of acid blue 80 by crude laccase from $L$ polychrous.

The effect of temperature was examined by incubating the reaction mixture at temperatures between 30 and $60{ }^{\circ} \mathrm{C}$. The initial reaction rate increased with increasing the temperature However, enzyme deactivation occurred when the temperature was further increased. The effect of temperature on enzyme kinetics is often described by the Arrhenius equation. Then Arrhenius plot between Log of initial reaction rate and $1 / \mathrm{T}$ was established. Activation energy was calculated from a slope equal to $-\mathrm{Ea} / 2.303 \mathrm{R}$. The correlation of the data provided a straight line. Therefore, activation energy for crude laccase on decolorization of Acid Blue 80 was $14.25 \mathrm{~kJ} / \mathrm{mol}$.

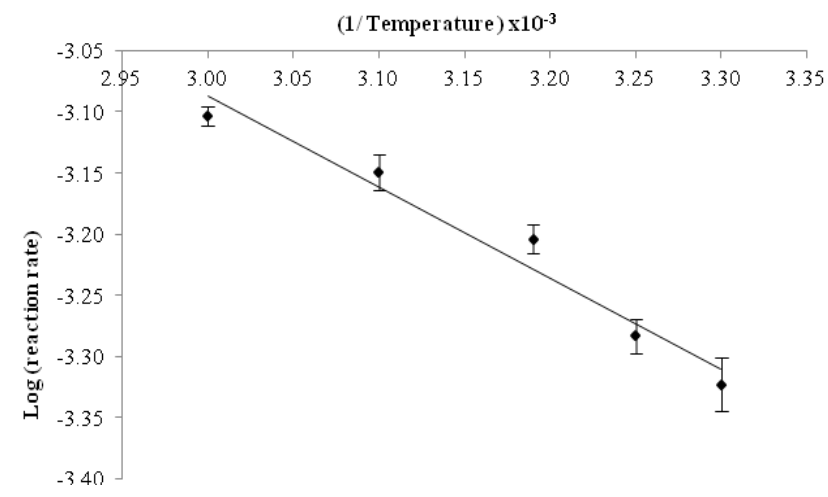

Fig. 5. Effect of temperature on initial reaction rate of decolorization by crude laccase from L. polychrous.

\section{CONCLUSION}

Laccase production was increased in the presence of copper and reached a maximum activity of $145 \mathrm{U} / \mathrm{ml}$ on $12^{\text {th }}$ day of cultivation. The decolorization of several dyes by crude laccase from L. polychrous was determined. Among the seven dyes, crude laccase had an obvious potential to decolorize anthraquinonic dye. Acid Blue 80 was decolorized about $85 \%$ in 120 min. In addition laccase activity and initial Acid Blue 80 concentration affect the performance of decolorization and the reaction kinetics can be satisfactorily followed Michaelis-Menten model. The most suitable $\mathrm{pH}$ for Acid Blue 80 decolorization was at $\mathrm{pH}$ 5.0. The initial decolorized rate increased with temperature $\left(30-60{ }^{0} \mathrm{C}\right)$. The activation energy of crude laccase was $14.25 \mathrm{~kJ} / \mathrm{mol}$. It can be concluded that crude laccase from L.polychrous is an effective enzyme for decolorization especially anthraquinonic dye. The application of this enzyme on real treatment of textile effluents should be further study.

\section{ACKNOWLEDGMENT}

This work was financially supported by a research grant of the Ubon Ratchathani University, Thailand. The authors also thank to Chemical Engineering Department, Faculty of Engineering, Ubon Ratchathani University and Biology Department, Faculty of Science, Mahasarakham University for supported equipment and work place.

\section{REFERENCES}

[1] E. Grassi, P. Scodeller, N. Filiel, R. Carballo, and L. Levin, "Potential of Trametes trogii culture fluids and its purified laccase for the decolorization of different types of recalcitrant dyes without the addition of redox mediators," International Biodeterioration and Biodegradation, vol. 65, pp. 635-643, 2011.

[2] I. Ciullini, S. Tilli, A. Scozzafava, and F. Briganti, "Fungal laccase, cellobiose dehydrogenase, and chemical mediators: Combined actions for the decolorization of different classes of textile dyes," Bioresource Technology, vol. 99, pp. 7003-7010, 2008.

[3] T. Mechichi, N. Mhiri, and S. Sayadi, "Remazol Brilliant Blue R decolourization by the laccase from Trametes trogii," Chemosphere, vol. 64, pp. 998-1005, 2006.

[4] H. R. K. Hamedaani, A. Sakurai, and M. Sakakibara, "Decolorization of synthetic dyes by a new manganese peroxidase-producing white rot fungus," Dyes and Pigments, vol. 72, pp. 157-162, 2007.

[5] S. Georgieva, T. Godjevargova, D. G. Mita, N. Diano, C. Menale, C. Nicolucci, C. R. Carratelli, L. Mita, and E. Golovinsky, "Non-isothermal bioremediation of waters polluted by phenol and some of its derivatives by laccase covalently immobilized on polypropylene membranes," Journal of Molecular Catalysis B: Enzymatic, vol. 66, pp. 210-218, 2010.

[6] S. S. Kahraman and I. H. Gurdal, "Effect of synthetic and natural culture media on laccase production by white rot fungi," Bioresource Technology, vol. 82, pp. 215-217, 2002.

[7] C. Galhaup, H. Wagner, B. Hinterstoisser, and D. Haltrich, "Increased production of laccase by the wood-degrading basidiomycete Trametes pubescens," Enzyme and Microbial Technology, vol. 30, pp. 529-536, 2002.

[8] R. Sarnthima, S. Khammuang, and J. Svasti, "Extracellular ligninolytic enzymes by Lentinus polychrous Lév. under solid-state fermentation of potential agro-industrial wastes and their effectiveness in decolorization of synthetic dyes," Biotechnology and Bioprocess Engineering, vol. 14, pp. 513-522, 2009.

[9] P. Suwannawong, S. Khammuang, and R. Sarnthima, "Decolorization of rhodamine B and congo red by partial purified laccase from Lentinus polychrous Lév.," Journal of Biochemical Technology, vol. 2, pp. 182-186, 2010.

[10] P. Baldrian and J. Gabriel, "Copper and cadmium increase laccase activity in Pleurotus ostreatus," FEMS Microbiology Letters, vol. 206, pp. 69-74, 2002.

[11] H. Z. Mechichi, T. Mechichi, A. Dhouib, S. Sayadi, A. T. Martínez, and M. J. Martínez, "Laccase purification and characterization from Trametes trogii isolated in Tunisia: decolorization of textile dyes by the purified enzyme," Enzyme and Microbial Technology, vol. 39, pp. 141-148, 2006. 
[12] X. Zheng, I. S. Ng, C. Ye, B.-Y. Chen, and Y. Lu, "Copper ion-stimulated McoA-laccase production and enzyme characterization in Proteus hauseri ZMd44," Journal of Bioscience and Bioengineering, vol. 115, pp. 388-393, 2013.

[13] K. Murugesan, Y.-M. Kim, J.-R. Jeon, and Y.-S. Chang, "Effect of metal ions on reactive dye decolorization by laccase from Ganoderma lucidum," Journal of Hazardous Materials, vol. 168, pp. 523-529, 2009.

[14] M. Lorenzo, D. Moldes, S. R. Couto, and M. Sanromán, "Inhibition of laccase activity from Trametes versicolor by heavy metals and organic compounds," Chemosphere, vol. 60, pp. 1124-1128, 2005.

[15] S. Kalme, S. Jadhav, M. Jadhav, and S. Govindwar, "Textile dye degrading laccase from Pseudomonas desmolyticum NCIM 2112," Enzyme and Microbial Technology, vol. 44, pp. 65-71, 2009.

[16] A. A. Telke, G. S. Ghodake, D. C. Kalyani, R. S. Dhanve, and S. P. Govindwar, "Biochemical characteristics of a textile dye degrading extracellular laccase from a Bacillus sp. ADR," Bioresource Technology, vol. 102, pp. 1752-1756, 2011.

[17] M. Zhang, F. Wu, Z. Wei, Y. Xiao, and W. Gong, "Characterization and decolorization ability of a laccase from Panus rudis," Enzyme and Microbial Technology, vol. 39, pp. 92-97, 2006.
[18] P. P. Champagne and J. A. Ramsay, "Dye decolorization and detoxification by laccase immobilized on porous glass beads," Bioresource Technology, vol. 101, 2010, pp. 2230-2235.

[19] A. Michniewicz, S. Ledakowicz, R. Ullrich, and M. Hofrichter "Kinetics of the enzymatic decolorization of textile dyes by laccase from Cerrena unicolor," Dyes and Pigments, vol. 77, pp. 295-302, 2008.

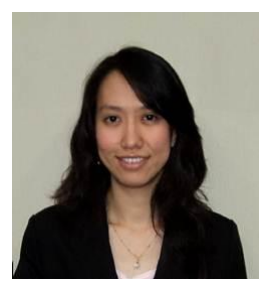

Karnika Ratanapongleka received her B.Sc.in Biotechnology from Khon Kaen University (Thailand), M.Sc. in Biotechnology from University of Western Sydney (Australia), and Ph.D. in Chemical Engineering from University of Wales Swansea (U.K.). She is currently an assistant professor in the Department of Chemical Engineering, Ubon Ratchathani University, Thailand. Her research interests include enzyme technology, membrane separation, membrane reactor, and fermentation technology 